\title{
An Analysis of the Ecofeminist Viewpoint on Industrialization and Environmental Degradation in Starhawk's The Fifth Sacred Thing
}

\author{
Fahimeh Sanati (Corresponding author) \\ School of Humanities, University of Science Malaysia \\ 11800 , Pulau Penang, Malaysia \\ Tel: 60-17-464-9104Ｅ-mail: sanati.fahimeh@gmail.com \\ Hessamaldin Nejati Hatamian \\ The School of Languages, Literacies and Translation, University of Science Malaysia \\ 11800, Pulau Penang, Malaysia \\ Tel: 60-17-484-9296 E-mail: hessnej@gmail.com \\ Associate Professor Dr. Tengku Sepora Tengku Mahadi \\ The School of Languages, Literacies and Translation, University of Science Malaysia \\ 11800, Pulau Penang, Malaysia \\ Tel: 60-12-407-8780Ｅ-mail: tsepora@usm.my
}

Received: January 20, 2011

Accepted: June 6, 2011

doi:10.5539/jsd.v4n4p86

\begin{abstract}
Ecofeminists call for a renewed ecological consciousness by integrating politics and the discourse of an embodied materialism. Their main intention is to interrogate patriarchal positions that prioritize men and marginalize women and nature. By addressing human exploitation of nature, this paper examines how the ecofeminist strategy for change does not necessarily overlook the advancement of technology. In other words, ecofeminism interrogates modern technology in order to negotiate better understanding of the domination of nature. This paper looks at how Starhawk applies an ecofeminist discourse, in her novel The Fifth Sacred Thing, in a way that reflects the capitalist patriarchal tactic of dividing and ruling lesser Others - namely women, the poor, peoples of color, and nature. The impact of industrialization and advancement of technology will be analyzed in relation to social well-being. This discussion addresses the fact that the advancement of technology may bring benefits to some but at the same time may cause natural disasters to others. Ecofeminist theory negotiates these emerging interfaces and revives socialist concerns for equity.
\end{abstract}

Keywords: Industrialization, Ecofeminism, Sustainable development, Environmental Degradation, Social Injustice

\section{Introduction}

Ecofeminism is defined as a movement whose main intention is to interrogate how the capitalist patriarchal position prioritizes men and marginalizes women and nature. In fact, ecofeminists believe that the destruction and exploitation of nature by men has its roots in the domination of women by men. In this respect their analysis is deeper and broader than that which concerns environmentalists. Whereas many environmentalists identify industrialization and new technologies as appropriate tools for economic growth, ecofeminists believe that the proliferation of technology should be balanced and more attention must be paid to pollution and natural resource preservation.

Nature has always been the most important resource for human beings, being available everywhere and free of charge. In the capitalist patriarchal world the use of natural resources has been manipulated excessively, as an economic tool to meet human economic requirements. Hence, it cannot be denied that nature has been sacrificed for the sake of industrialization. To illustrate this point, one can refer to many different cases of environmental negligence; Billions of trees have been chopped down and farms have been cleared to allow more space for housing and factories. Many people tend to believe that the clearing of land is a necessary effort to improve economic conditions, but an important aspect of the problem of technological development is that it disregards attempts to preserve and protect natural resources. Ecologists are concerned by the environmental devastation which poses a threat to the equilibrium between humans and nature. Ecofeminists are deeply worried about this crisis, and propose the need for greater awareness for nature conservation.

This research examines Starhawk's science fiction The Fifth Sacred Thing, to highlight how technology is a problem for people of the 'North'. In the North, at first sight, the reader might notice the rural area, depicted by gardens and flowing rivers. But the advancement in medical sciences and computer technologies are simultaneously portrayed in the North even though the ecofeminist society of the 'North' is so conservative about environment and natural resources. Therefore, examining ecofeminists' stance regarding technology and 
industrialization this analysis discusses how the development of technology brings benefits to some but at the same time causes natural disasters to others. In view of these facts, Ecofeminist theory negotiates these emerging interfaces and revives socialist concern towards kinds of industrialization that are "appropriate" and more sympathetic to nature perseverance.

\section{Review of the Related Literature on Ecofeminism and Industrialization}

Various studies have addressed industrialization through the lens of ecofeminism. Annabel Rodda (1991) states quite plainly that nature's deterioration results from human activities associated with industrialization. Rodda further asserts that unsustainable exploitation of natural resources and unsound agricultural practices have resulted in degradation of the natural environment. Other elements of modern capitalist patriarchal economic development, such as urbanization, globalization, and the development of an oil dependent transport system, as well as armed conflict all have major environmental impact.

Moreover, Maria Mies in her book Ecofeminism states that "technology...cannot claim to be neutral; nor is it free from sexist, racist and ultimately fascist biases in our society. These biases are built into the technology itself, they are not merely a matter of its application" (Mies \& Shiva, 1993, p. 195). Therefore, Mies does not believe in the neutrality of technology and she excoriated technology for its inherent features and consequences, including sexism and racism.

Ariel Salleh (1997) in her book Ecofeminism as Politics: nature, Marx and the postmodern, also argues the importance of sustainable development to maintain the equilibrium between humans and nature. And she is concerned that this term is being misused by advocates of economic globalization. She cites with approval the indigenous perspective of Winona LaDuke that "... reciprocal relations, defines as responsibilities and ways of relating between humans and the ecosystem ... thus, one could not take life [for food] without a reciprocal offering ... you take only what you need and leave the rest" (p. 146: LaDuke 1993, pp. 99-100). Hence, although it is allowable to take away some life, Salleh proposes the necessity of giving back, since human beings and nature need to co-exist together.

Similarly, Jennifer Micale (2002) in Strange New Worlds: Ecofeminism and Science Fiction examines some science fiction, including The Fifth Sacred Thing, and focuses on how ecofeminist science fictions can help envision and create a community where we can truly live. Besides, analyzing The Fifth Sacred Thing, she also asserts that instead of going against or neglecting new technologies, futuristic ecofeminist cultures might introduce new technology in consonance with nature.

In support of Micale's viewpoint, Anna M. Martinson (2003) in Ecofeminist perspectives on technology in the science fiction of Marge Piercy, utilizes three feminist approaches to argue about gender and technology. She poses that "ecofeminist arguments are rarely truly anti-technology. Rather, they place an emphasis on 'appropriate' technology which holds central the relationships between technology and society and the impact of technology on the environment" (p. 12). Unlike the ecofeminist Mies who believes technology cannot claim to be neutral, Martinson, who seems to be a liberal feminist, declares that it is not the model of technology that makes it negative or positive; but rather it is the way people use technology.

Alternatively, Karen Hurley (2008) points to visions of the future in recent movies in her journal article entitled Is That a Future We Want?: an Ecofeminist Exploration of Images of the Future in Contemporary Film. She criticizes the viewpoint illustrated in these films since it "limits the future to a Western high-tech, white, heterosexual, patriarchal, militaristic, dark blandness where a small number of the rich and powerful men are in control" (p. 346). Hurley argues that democracy, social and biological diversity are significant components of an ecologically and socially just future and that filmmakers have great power to show to the world.

On the same note, Salleh (2009) in her article The Dystopia of Technoscience: an Ecofeminist Critique of Postmodern Reason rejects Haraway's cyborg manifesto. She believes that by introducing the concept of cyborg, Haraway supports "capitalist patriarchal technoscience... [which] presents a dystopia that confuses the political focus of feminism ... and consumes the support system of all life on earth" (p. 201). In contrast to the resource greedy technologies of capitalist patriarchal economics, Salleh supports simpler forms of social organization which can sustain can human needs while still regenerative of nature.

Furthermore, Melanie Ahkin (2010) explains that ecofeminist Val Plumwood criticizes the "human chauvinism" of western culture and much of its environmental ethics (p. 1). Plumwood's suggestion is to expand a set of cooperative and interspecies communicative ethics empty of any kind of dualism and hierarchy. Therefore, Ahkin promotes ecological feminism for its critique of any oppressive structure and its proposal for an anti-dualistic scaffold. In view of these observations, this paper examines how a form of technology might be developed in an effort to preserve nature. Hence, Starhawk's suggestions and practical solutions, in her novel, will be analyzed to show how humans can benefit from technology while preserving nature.

\section{Research Method}

Selected excerpts from the novel The Fifth Sacred Thing will be analyzed in this qualitative study through an ecofeminist lens to shed light on industrialization and technological advancement and their advantages and 
disadvantages. This discussion demonstrates the impact of utilizing unsustainable technology in human life through carrying out a thematic analysis on the novel. It will also focus on the consequences of technological development applied without an environmental ethic, so leading to the oppression of other human beings such as women, poor people and people of colour. Besides, the domination of nature and environmental degradation will be analyzed as well to awaken public awareness of the long-term consequences of utilizing nature for technological development. In the discussion, the analysis of industrialization and the ill-effects of technological development without proper ethics will be examined in relation to social well-being. It will also be mentioned that, industrialization and advanced technology require depletion of many natural resources, leaving wastes and pollution instead. Thus, this study examines in what ways industrialization and new technologies can continue without causing any harm to nature or with the least damage possible. The analysis will highlight eco-critical concerns towards sustainable development and preserving natural resources and ecosystems. To accomplish these objectives, ecofeminist stances like Ariel Salleh, Greta Gaard, Mary Mellor and others will be utilized to analyze the advantages and disadvantages of technological development to human and nature.

\section{Sustainability and Technological Development in The Fifth Sacred Thing}

\subsection{Environmental Degradation in the 'South'}

Starhawk in her novel, The Fifth Sacred Thing, depicts people and human interactions with Mother Earth. In this ecotopian fiction situated in California, there is a struggle between the North that is San Francisco and the South that is Los Angeles. Natural elements such as air, fire, water, and earth that sustain all life are considered sacred and holy in the North and spirit is the fifth sacred element. All these natural elements are respected and cannot be owned. As illustrated in the novel, the population in the North does not suffer from poverty or famine, and everyone has enough to drink and eat and a place for shelter. Besides, the Northern part has been discussed to have a rich culture which honors its diverse mix of races, religions, and heritages. Conversely, the Southland is governed by an authoritarian regime, the Stewards, which rules through a religious fanaticism, in which racism, sexism, and the oppression of the lower classes have been institutionalized, in order to sustain in power. In this discriminative society, women, poor people and people of colour are treated as second class citizens who have almost no social power or rights. The green lands, forests and agricultural farms have been destroyed in exchange for industrial buildings. In addition, as Starhawk conveys, utilizing unsustainable technology including nuclear power and the thoughtless use of natural resources has ruined the natural environment and industrial waste has contaminated water reservoirs. These acts cause much damage to the inhabitants of the South.

Here, it is important to refer to Maria Mies' stance on technological development. Mies (Mies \& Shiva, 1993) describes technology as exhibiting four aspects. The first aspect indicates that the development of technology in a capitalist patriarchal society is not meant to make human beings happy but to allow continuing accumulation of profit. Secondly, as a historical fact, technological innovations result in social exploitation and inequality. It has been proven that industrialization and technological development lead to exploitation of marginalized classes in human society. The third aspect focuses on biotechnologies that are designed to manipulate and appropriate women's ability to reproduce, so reducing their human dignity. Finally, the fourth aspect that Mies suggests is that the merits and demerits of a technology depend on its application, its accessibility for all people and its effect on social relations. However, as Mies states, feminists demonstrate that domination in society is a major element of technology (pp. 174-175). Moreover, in her other studies, Mies (1985) reemphasizes that reproductive or genetic technology should be criticized harshly so as to prevent the further destruction of humans and nature. Mies (1986) also maintains that the economic exploitation of nature, sexism, racism, fascism and subordination of poor people lies at the heart of new productive technologies.

Environmental degradation is one of the key themes conveyed by Starhawk. Through the reading of the novel, The Fifth Sacred Thing, it is noticeable that water pollution and air contamination are evidence of environmental devastation. In the South, the Stewards deforest the jungles in order to use the wood in industry and replace the open lands with new buildings instead. Besides, nuclear power is employed as a significant energy resource and lots of sophisticated and modern firearms are produced in the South for the sake of national security. As a result of industrialization and nuclear waste, both landscapes and seawater have been poisoned and polluted and are beyond use. In addition, as the author conveys, air pollution has caused considerable damage to the ozone layer which has made flying almost impossible (Starhawk, 1993, p. 17). On the other hand, water supplies are owned by the government and not available for everyone to use. The scarce water supplies are rationed and only the rich can afford to have more. In view of such a scenario, we should accept Mies's claims regarding technology. It cannot be ignored that in the South as characterized by Starhawk, industrialization and technology have been exploited by the ruling class to help them remain in power. The destruction of natural environment and the marginalization of many vulnerable groups including women, the poor and colored people are interlinked.

\subsection{Social Injustice as a result of Unsustainable Development}

The public in general tend to believe that in industrialized and technologically developed societies people are able to live happily and comfortably. On the other hand, as the author would have us believe, the consequences and ill effects of unsustainable development will result in many irreversible problems. Starhawk writes that 
unsustainable technology in the South has brought different negative effects within itself. To illustrate this point, one can refer to the figure of Morton who has escaped from the South and lives in the hills. Morton conveys "we're ... all born back when the old reactor was still running ... what the hell did they [the South government] care? Of course, you don't see the ones who died of cancer" (p. 92). Hence, it is noticeable that cancer has turned out to be very common among people and more to the point, everybody needs to take some prescribed pills, namely "boosters", to immunize his or her body against different diseases (p. 103). Moreover, one cannot deny the fact that, in addition to health problems, the unsustainable technology can give rise to domination of one group of people over others. Subsequently, one can agree with social ecologist Murray Bookchin (2004) that although turning nature into a commodity has been euphemized as growth, industrial society or urban blight, the process has its roots in the domination of human by human. As Starhawk highlights, through taking advantage of vulnerable social groups and exploiting them as labor, the totalitarian government of the South benefits from their hard work and maintains itself in power.

Another important aspect of the social injustice in this Dystopia is the fact that women are forbidden by the law to have important jobs. As Starhawk describes the situation, the South government devalued women's work and deprived them of many of their inalienable social rights. Beth as former gynecologists in the South says: "they [the Police] dressed us in prison clothes and locked us up in separate cells, where we remained for a week. When our lawyer finally reached us, he advised us to sign a confession, take the Oath of Repudiation, recant" (p. 325). Therefore, women were coerced to set their licenses and diplomas on fire and quit their jobs. Through these remarks, Starhawk reveals the real face of industrialized and technological society of the South in which the natural environment and resources are depleted and vulnerable groups of society are marginalized and exploited. Accordingly, environmental devastation is not the only consequence of unsustainable development; other problems such as the exploitation and domination of women, the poor and people of colour will come hand in hand with it.

\subsection{Utilizing Renewable Energy Resources in the North}

Comparing the situation of her fictionalized South with the North, Starhawk's novel provides some solutions for environmental problems to maintain the equilibrium between humans and nature. Take for example Madrone's description of Utopia to the South people. She talks about the five sacred things which are earth, air, fire, water and spirit and the fact that they are respected and cannot be owned. Besides, Madrone narrates that to have a right relation with these sacred elements we need to "preserve them and protect them, never to waste them, always to share what we have of them and to return all we take from them to the cycles of regeneration. Together, they form ... the cycle of life" (p. 300). Hence, the author makes us realize that the relationship between humans and nature needs to be based on sustainability and caring for nature. Therefore, we should not ignore the fact that social development is not always about taking and benefiting from nature; nature also needs to be nurtured to maintain, because all human and non-human lives depend on it. Taking these points into consideration, people of the North value nature and attempt to compensate for the damages that have been done to it over the years. Take for example planting trees; people of Utopia go up to the mountains every year and plant thousands of trees (p. 299). Moreover, in order to reduce the air pollution the number of cars has been lessened. Instead, public transportation is largely used because it is free and convenient. Therefore, it is noticeable that People care about their natural environment and prefer to walk or use bicycles in order not to produce air pollution (p. 18).

Starhawk refers to the importance of sustainability as a way for society to "generate or save as much energy as it consumes and doesn't depend on non-renewable resources" in her novel (p. 275). This will lead us to realize that we can get help from nature and use the natural resources as long as we can return them to nature to avoid doing anything which results in destruction or waste of energy. To illustrate this point further, Starhawk describes the construction techniques used in buildings in the North. It is clear from the novel that elevators and air conditioning systems were not used in high buildings; instead, windows were installed where they admitted a breeze. Moreover, the energy of currents and tides are utilized to produce the major electrical power which is accompanied by solar panels and wind generators. In addition, natural techniques and materials are utilized in buildings, such as wood, bamboo, adobe and straw. Besides, papers are made out of hemp and use soy-based and corn-based plastics in order not to cause any further devastation to nature and its resources. Furthermore, a very progressive computer technology exists in the North which operates based on crystals (p.275). Although the applied technology and energy are designed to be modernized, they are also based on renewable resources. In other words, as the author makes us realize, technology in the North has been allowed to develop only to the extent that it is compatible with environmental preservation.

As Greta Gaard (2001) indicates, ecofeminism is a movement that fosters awareness toward the everyday problems of environmental degradation and social injustice more than merely a theory about feminism and environmentalism or women and nature. Accordingly, Gaard's stance regarding environmental degradation and social injustice strengthens the claim that the way human beings treat nature eventually reflects the way they treat each other. In Madrone's words, despite all differences in people's beliefs in the Utopia, they have reached consensus on respecting five sacred things, earth, air, fire, water and spirit (p.300). Therefore, the moral of 
Starhawk's story is that by protecting nature and respecting one another, people of North could survive the ecological crises after the uprising and manage to start a green and egalitarian society.

\section{Conclusion}

The idea of an embodied materialism in ecofeminism shifts concern from the material means of production to practical life-oriented solutions for environmental and social problems. The crisis that is created as a result of unsustainable capitalist patriarchal growth and its technologies cannot be solved and compensated for by more of the same. Mary Mellor, echoing Bookchin, argues that a good society is an ecological society. It does not transcend natural conditions or ecological boundaries and people do not take more than what they need (Bookchin, 1980; Mellor, 1997). Hence, environmental resources will sustain and regenerate only when this respect for nature appears in human societies. Starhawk believes that technological development can still exist within a framework of sustainability. Starhawk and Plumwood tend to believe that ethics and spiritual understandings are sufficient tools for change, whereas Mies and Salleh challenge the global economic system. On the other hand, ecofeminists also argue for equality of all humans regardless of their gender, race and economic positions. Consequently, as the title of The Fifth Sacred Thing implies, when all people respect the four sacred things including earth, air, water and fire, they can reach the fifth sacred thing which is spirit. Hence, in the light of respecting one another and the natural environment, people can experience freedom, sustenance and nourishment in every society. But this said, most ecofeminists negotiate for better understanding of the domination of nature by the means of production. And they do this in order to highlight the too often unanticipated effects of technology including the social injustices that it can bring. As Maria Mies and Vandana Shiva put it: "In nature's economy, the currency is not money, it is life." (Mies \& Shiva, 1993, p. 270).

\section{References}

Ahkin, M. (2010). Human Centrism, Animist Materialism, And The Critique Of Rationalism In Val Plumwood's Critical Ecological Feminism. Emergent Australasian Philosophers 3, 1-25.

Bookchin, M. (1980). Toward an ecological society, Montreal: Black Rose Books.

Bookchin, M. (2004). Post-scarcity anarchism, California: AK Pr Distribution.

Gaard, G. (2001). Women, Water, Energy: An Ecofeminist Approach. Organization \& Environment, 14, 157-172. doi:10.1177/1086026601142002

Haraway, D. (1991). Simians, cyborgs, and women: The reinvention cfnature. New York: Routledge.

Hurley, K. (2008). Is that a future we want?: An ecofeminist exploration of images of the future in contemporary film. Futures, 40(4), 346-359. doi: 10.1016/j.futures.2007.08.007

LaDuke, W. (1993). A Society Based on Conquest Cannot be Sustained. In R. Hofricher (Ed). TOXIC struggles (pp. 99-100) Philadelphia: New Society.

Martinson, A. (2003). Ecofeminist Perspectives on Technology in the Science Fiction of Marge Piercy. Extrapolation, 44(1), 50-68.

Mellor, M. (1997). Feminism \& ecology. Cambridge: Polity press.

Micale, J. (2002). Strange New Worlds: Ecofeminism and Science Fiction. Unpublished Doctoral dissertation, New Jersey: Drew University.

Mies, M. (1985). Why Do We Need All This? a Call against Genetic Engineering and Reproductive Technology. Women's Studies International Forum, Vol. 8, No. 6. doi:10.1016/0277-5395(85)90093-7

Mies, M. (1986). Patriarchy and Accumulation on a World Scale: Women in the International Division of Labour: London: Zed Books.

Mies, M. \& Shiva. V. (1993). Ecofeminism. London: Zed Press.

Rodda, A. (1991). Women and the Environment. London: Zed Press.

Salleh, A. (1997). Ecofeminism as Politics: nature, Marx and the postmodern: London \& New York: Zed Books.

Salleh, A. (2009). The dystopia of technoscience: An ecofeminist critique of postmodern reason. Futures, 41 (4), 201-209. doi: 10.1016/j.futures.2008.09.003

Starhawk. (1993). The Fifth Sacred Thing. New York: Bantam books. 